\title{
Plante de leac între sacru și profan
}

\author{
Delia-Anamaria RĂCHișan \\ Universitatea Tehnică din Cluj-Napoca, \\ Centrul Universitar Nord Baia Mare, România
}

\section{Medicinal herbs between sacred and profane}

\begin{abstract}
This paper aims to highlight the regional names of some healing plants, pointing out the fragile boundary between the sacred and the profane. Some plants are anthropomorphized (mandragora), while others can be correlated with legends (chicory, milfoil, etc.), celebrations (daffodil, garlic, lily of the valley, Năvalnicul 'hart's-tongue', Sânzienele 'lady's bedstraw', etc.), mythology (Sita-Ielelor 'silver thistle', snowdrop), charms, elements of Christian worship, and iconic personalities who suffered martyrdom.

Regional or euphemistic names tend to anthropomorphize or change the way plants are seen by a community and even to desecrate or sanctify them. The critical angles of approach to regional names, which focus on isotopes (agrarian, avimorphous, human, vegetal, dendromorphic, superhuman or zoomorphic) and semantic relations of antonymy/synonymy, facilitate the transition from ethnology towards linguistics and underline the sacred-profane dichotomy.
\end{abstract}

Keywords: sacred, profane, medicinal herbs, regional names.

\section{Introducere}

Pornind de la dihotomia sacru-profan avem în vedere anumite paliere: denumirea știinţifică și denumirile regionale ale unor plante de leac; impactul acestora asupra savanților și asupra mentalului colectiv; perspectiva interdisciplinară (lingvistică, folclor, etnologie, mitologie, religie); relația care se instituie între plante și sărbători; antropomorfizarea; corelarea cu anumite categorii folclorice (legende, descântece); izotopiile (agrară, avimorfă, fitomorfă, gastronomică, dendromorfă, supraumană, umană, zoomorfă); funcțiile fundamentale și subsidiare; rolul taumaturgic. Palierele abordate evidențiază cât de fragilă este granița care se instituie între sacru și profan. Plantele fiind ambivalente (benefice-malefice) sesizăm o dialectică a contrariilor care se armonizează: medicament-otravă; sacru-profan; leac pentru suflet-leac pentru trup. Perspectiva interdisciplinară, unghiurile critice de abordare (lingvistic, etnologic, religios, mitologic) subliniază unitatea în diversitate și rolul taumaturgic al plantelor. Glisarea dinspre etnologie înspre lingvistică, augmentată de binaritatea sacru-profan, relevă impactul plantelor de leac asupra oamenilor trăitori în lumea satului românesc. Denumirile regionale, apelativele eufemistice au capacitatea de a antropomorfiza, de a 
„îmbuna” sau de a (de)sacraliza plantele. (Re)descoperind universul plantelor, aflăm că regnul vegetal posedă un limbaj accesibil inițiaților. În popor se crede că neinițiații pot decripta limbajul plantelor doar dacă, de exemplu, se hrănesc cu carne de șarpe alb (Butură 1992: 220). Dacă ne raportăm la anumite categorii folclorice (legende, basme), binaritatea sacru-profan se întrevede și la nivelul relației care se instituie între Fârtat și Nefârtat, adică între principiul major (Dumnezeu) și principiul minor (Diavol). Conform mentalităţii oamenilor din societatea tradițională, raportându-ne la legende și basme, remarcăm că Dumnezeu și Necuratul sunt antropomorfizați. Se crede că pe unde pășește Dumnezeu cresc flori, crește iarbă, iar pe unde calcă Satan, își fac apariția scaieții, urzicile, spinii, măselarița etc. Consubstanțialitatea om-natură apare și în Sfânta Scriptură, în Facerea: „Și a zis Dumnezeu: «Să dea pământul din sine verdeață: iarbă cu sămânță într-însa, după felul și asemănarea ei, și pomi roditori, care să dea rod cu sămânță în sine, după fel, pe pământ!» Și a fost așa” (Biblia 1997: 1/3, $11)$.

De-a lungul timpului, denumirea plantelor a fost influențată, în mod general, de gândirea empirică a oamenilor trăitori în mediul rural și, în mod special, de gândirea savanților. Suntem în asentimentul lui Ioan Milică (2010), atunci când conchide că numele de plante, cu rezonanță creștină, sunt cele dezvoltate prin subordonare acuzativală și prin subordonare genitivală; că predomină două modele denominative - popular/ naiv și savant. Modelul denominativ popular/naiv se bazează pe o gândire empirică, iar modelul denominativ savant vizează o gândire riguroasă, științifică${ }^{1}$.

\section{Plantele și sărbătorile. Dihotomia sacru-profan}

Sărbătoarea (lat. servatoria, servo, -are „a păstra”; „a conserva”; „a respecta”/festum, -i „,sărbătoare") determină trăire colectivă, trăire în timp sacru, suprimarea timpului profan și prefacerea duratei în clipă eternă. Pe perioada sărbătorii, timpul profan se dislocă în favoarea timpului sacru: „Timpul este neîntrerupt și pentru a-l putea înțelege, oamenii l-au tăiat în felii și au creat Anul; pe felii este o tăietură: această tăietură este sărbătoarea" (Pop 1998: 259). Dacă pornim de la premisa că primele flori, că primele roade aparțin Domnului, sesizăm sacrificiul vegetal și respectul oamenilor din mediul rural față de simbolurile fitomorfe care au rol de „primiții”: „Această acțiune cu funcție rituală la bază, desacralizată în timp, este primul sacrificiu vegetal cu rol de «primiții» (primele roade, primele fructe sunt ale Domnului, precum primul animal născut), care oferea și garanția de puritate, calitate absolut necesară în orice moment de trecere din cadrul complexelor rituale ample care reglementează existența umană” (Ispas 2015: 47).

Corelăm anumite plante cu sărbători întâlnite în Calendarul Popular:

1 În popor, plantele sunt denumite „buruieni”, ceea ce implică o denominație vagă la nivelul numelor compuse [buruiană + determinant]. Alteori, denumirile compuse vizează și alți termeni etnobotanici: iarbă, floare. Oferim câteva exemple în acest sens: buruiană dulce, iarba fiarelor, floarea-soarelui. Exemple de denumiri științifice, precum Allium sativum, Atropa Belladonna, urmează să le decriptăm în acest studiu. 
$\mathbf{a}_{1}$ Dragobete (primele flori de primăvară);

$\mathbf{a}_{2}$ Sângiorz (lăcrimioarele, narcisele);

a 3 Sângiorz, Sântandrei, Sântvasăi (aiul);

$\mathbf{a}_{4}$ Drăgaica/Sânzienele (sânzienele);

a Paşti (floarea-Paștelui, vioreaua).

b. Totodată, avem în vedere denumirile regionale ale unor sărbători care pot fi asociate cu fitonime (Măcinici-Brândușe).

$a_{1}$ Conform mentalității tradiționale, de sărbătoarea Dragobete (Calendarul Popular)/de Aflarea Capului Sfântului Ioan Botezătorul (24 Februarie/Făurar, Calendarul Creștin), denumită în mediul rural și Cap de Primăvară, se culeg primele flori care se ivesc de sub zăpadă. Menționăm și alte denumiri regionale: Bragobete, Bragovete, Cap de Vară, Cap de martie, Drăgobete, Drăgostițele, Gabrovete, Ioan Dragobete, Însoțitul Păsărilor, Logodna Păsărilor, Logodiciul Păsărilor, Sânt' Ioan de Primăvară, Ziua Dragostelor. Totodată, semnalăm faptul că sărbătoarea este variabilă de la o zonă etnografică la alta, ceea ce înseamnă că sărbătoarea alocată dragostei curate şi nevinovate poate avea loc în date diferite: „2 24 și 28 februarie; 1 și 25 martie” (Ghinoiu 2002: 229). Raportându-ne la simbolurile fitomorfe și la registrul sacru-profan, remarcăm, la nivel simbolic, relația care se instituie între echinocțiul de primăvară și solstițiul de vară. În mediul rural, de Dragobete (24 Făurar/Februarie) și de Sânziene/Drăgaica (24 Cireșar/ Iunie), și în prezent, se culeg flori de primăvară (ghiocei, brândușe, lușcuțe) și flori de vară (sânziene, trandafiri sălbatici). Simbolurile fitomorfe specifice (primă)verii se aruncă pe apă - râu, izvor. Exemplificăm anumite funcții fundamentale: funcție de inițiere, funcție de mediere conștientizată între microcosmos și macrocosmos etc. În popor există convingerea că împreunarea florilor surori este de bun augur: „Tradiția susţine că împreunarea florilor surori, vitregite de natură să nu se întâlnească niciodată, echivala cu o faptă bună, reprezentând jumătate de «sărindar»" (Ghinoiu 2002: 228). A aduna și a lăsa pe apă astfel de flori echivalează cu iertarea păcatelor²

Dragobete cu tema drag- (slava veche dragu, biti „a fi drag”) este un termen care poate fi analizat după nume de sărbători și după denotat: Dragobete-sărbătoare; Dragobete-antroponim. Termenul „dragobeți” este polisemantic, având legătură și cu regnul vegetal ${ }^{3}$ :

$\mathbf{a}_{\mathbf{1 i}}$ izotopie umană: feciorii cuprinși de primii fiori ai dragostei;

$\mathbf{a}_{1 i i}$ izotopie dendromorfă: mugurii culeși de pe pomi și acroșați de fete la ureche.

$\mathbf{a}_{\text {liii }}$ izotopie zoomorfă: denumirea unor gândaci folosiți în descântecele de dragoste (gândacul „repede", Cicindela campestris).

Dacă ne raportăm la tema drag- și la substantivul dragoste, descoperim planta drăgostiță (Sedum maximum), fitonim utilizat în descântecele de dragoste [subst.

$2 \mathrm{Nu}$ întâmplător, termenul „sărindar”, conform Dicționarului explicativ al limbii române, are un status aparte: „rugăciune de pomenire făcută de preot timp de patruzeci de zile în șir pentru morți, pentru iertarea păcatelor, pentru bolnavi” (DEX 1998: 952).

3 Vezi detalii despre polisemantismul termenului „dragobeți” la Răchișan 2015: 807-810. 
dragoste + sufixul -iță]. Extrapolând, planta Dragoste (Sedum fabaria), denumită și Masa Raiului stă sub tutela sacrului, conferă armonie familiilor care o plantează în grădinile lor.

Raportându-ne la sărbătoarea Dragobete, conform mentalului colectiv, sesizăm legătura personajului Dragobete cu planta Năvalnic (Phyllitis scolopendrium, fam. Polypodiaceae) și cu Maica Domnului.

\section{Denumiri regionale:}

$\mathbf{a}_{1 x}$ izotopie fitomorfă: Ferigă;

$\mathbf{a}_{1 \mathbf{x x}}$ izotopie zoomorfă: Limba cerbului, Limba boului, Limba vacii;

$\mathbf{a}_{1 \mathbf{x x}}$ izotopie antropomorfă: Limba vecinei, Limbariță;

$\mathbf{a}_{1 \times x x x}$ izotopie supraumană: Spata dracului;

$\mathbf{a}_{1 \times x x x x}$ izotopie astrală: Razele soarelui.

$\mathbf{a}_{1 y}$ Năvalnicul și legendele

Se crede că, inițial, Năvalnic a fost un fecior chipeș și iubăreț: „acesta umblă prin pădure și sărută fetele" (Ghinoiu 2013: 108). Conform unei legende, flăcăul Năvalnic ar fi speriat-o pe Maica Domnului care ar fi avut Pruncul în brațe. Dintr-o altă legendă aflăm că din pricina lui, Maica Domnului s-ar fi rătăcit prin pădure. Drept pedeapsă, flăcăul este metamorfozat în planta omonimă: „- Năvalnic ești, Năvalnic să fii!/Între buruienile de dragoste ești,/Buruiană de dragoste să rămâi!" (Ghinoiu 2013: 204). Chiar dacă este supus metamorfozării, simbolul fitomorf nu își pierde status-ul inițial. Dacă pornim de la premisa că de sărbătoarea Dragobete se pune accent pe dragostea nevinovată, atunci putem afirma că planta Năvalnic stă sub tutela sacrului. Planta Năvalnic trebuie culeasă, chiar de sărbătoarea Dragobete, respectându-se praxis-ul ritualic: „descoperirea locului unde crește; prosternarea și efectuarea semnului crucii; depunerea ofrandelor (sare, pâine, zahăr) la rădăcina acestuia" (Ghinoiu 2005: 49-50). Planta, culeasă cu tot cu rădăcină, era aşezată la loc de cinste: în sân, în scalda nou-născutului, la brâu, sub streașina casei. Planta întrunește anumite funcții: erotică, oraculară, de inițiere, de fecunditate, magică, primând funcția magico-erotică: „Acasă pun buruienile săpate după icoană, de unde nu le iau decât atunci când pleacă la joc, când le pun la brâu, crezând că vor fi jucate de feciori, întocmai cum au jucat și ele cu acele buruieni” (Pamfile 1998: 24). Dragobete, asociat cu Cupidon sau cu Eros din mitologie, propovăduiește statornicia, armonia, dragostea curată.

$\mathbf{a}_{\mathbf{1 z}}$ Zburătorul și legendele

La polul opus, Zburătorul generează dezechilibru, chinuie fetele, văduvele, se crede că poate surveni decesul acestora. Zburătorul este denumit ceas rău/lipitură. Și Zburătorul are planta sa: „zburătoare mică”/„zburătoare” (Veronica longifolia). Planta este procurată ca leac contra ceasului-rău. Legenda, în care se înfiripă o poveste de dragoste între o fată și Zburător, este redată de Simion Florea Marian în studiul Botanică românească (2000: 125-129). Redăm succint legenda: „Mama fetei, apelând la o 
femeie iniţiată va procura prin intermediul fetei, de la Zburător, buruiana numită $z b u$ rătoare pentru a vindeca vaca din gospodărie. Performera va apela, de fapt, la un şiretlic, animalul-victimă fiind doar un pretext. Mama își va uda fata cu leacul preparat de femeia inițiată (femeia apelează la magia albă și termenul cel mai potrivit ar fi cel de descântătoare, nu cel de «vrăjitoare» întâlnit în legendă) salvând-o, utilizând iarba Zburătorului. Leacul obținut prin fierberea plantei, apa din ulcică, decoctul are valoare soteriologică, funcție apotropaică” (Răchișan 2013: 171). 129).

Rol taumaturgic (medicina populară): tuse, răni, „fierbințeală” (Borza 1968:

$\mathbf{a}_{2}$ Narcisele și lăcrimioarele pot fi corelate cu sărbătoarea Sângiorz [Sfântul Gheorghe].

$\mathbf{a}_{2 \mathrm{i}}$ Narcisa (Narcisus poëticus L. ssp. radiiflorus, fam. Amaryllidaceae) poate fi asociată cu sărbătoarea Sângiorz [Sfântul Gheorghe]: „Florile se puneau, cu alte plante, în cununile cu care se împodobeau vasele de lapte, la Sângiorz; după trei zile, cununile se dădeau la vite" (Butură 1979: 165).

$\mathbf{a}_{2 \mathrm{ii}}$ Lăcrimioarele (Convallaria majalis L., fam. Liliaceae) ne duc cu gândul la sărbătoarea Sfântul Gheorghe datorită anumitor denumiri regionale: „giorgițe, iarba Sfântului Gheorghe" (Pârvu 2003: II, D-L, 568).

$\mathbf{a}_{3}$ Datorită funcției „apotropaice” [de apărare], aiul (lat. Allium sativum) este acroșat, în ajun de Sângiorz [Sfântul Gheorghe], de Sântandrei [Sfântul Andrei], de Sântvasâi [Sfântul Vasile], la ferestrele, ușile, streașinile caselor, inclusiv la ușile grajdului pentru a apăra vitele de forțele malefice. Se crede că denumirea plantei a fost dată de Dumnezeu. Aiul stă sub tutela sacrului. Aiul, denumit și usturoi, se deosebește prin denumire de usturoiul sălbatic, adică de samuraslă (lat. Allium vineale).

Denumiri regionale ${ }^{4} \mathrm{cu}$ trimitere la:

$\mathbf{a}_{3 \mathrm{i}}$ anotimp: Ai de primăvară, Usturoi de primăvară, Ai de vară, Usturoi de vară, $A i$ de toamnă, Usturoi de toamnă; Usturoi de iarnă;

$\mathbf{a}_{3 \mathrm{ii}}$ etnie: Ai jidovesc;

$\mathbf{a}_{3 \mathrm{iii}}$ înrudire+nonculoare: Ceapă albă.

Ioan Milică a constatat că anumite denumiri științifice sunt întemeiate prin anagramare $[$ Muilla < Allium $]$ : „Apariția denumirii formate prin anagramă este motivată de faptul că speciile de plante din genul Muilla, deși fac parte din familia crinului, au flori asemănătoare cu ale celor din genul Allium, acesta fiind fundamentul cognitiv care generează anagrama"s. Totodată, Ioan Milică, având în vedere dihotomia realitate-

4 Vezi și alte denumiri regionale la Borza 1968: 15.

5 I. Milică 2010. Modele naive și modele savante în reprezentarea lingvistică a realității: denumirile de plante, în Revista Limba Română, nr. 11-12, Anul XX, http://www.limbaromana.md/ index.php?go=articole\&n=1077. 
denumire, clarifică problema continuității și creativității denominative în ceea ce privește observarea asemănărilor și deosebirilor între modelul naiv și savant alocat termenului „ai”: „unii dintre termenii etnobotanici latini au fost moșteniți în limbile romanice și fac parte, astăzi, atât din tezaurul denominativ popular, cât și din terminologia botanică științifică. Un exemplu în acest sens este lat. al(l)ium ai cărui urmași romanici, rom. ai, it. aglio, prov. alh, fr. ail, cat. all, span. ajo, port. alho au drept corespondent științific lat. Allium, care denumește genul plantelor înrudite cu ceapa [...] lat. Allium a devenit termen științific universal, întrebuințat de toți botaniștii, indiferent de cultura din care fac parte și de limba pe care o vorbesc, în vreme ce cuvintele provenite din lat. al $(l)$ ium supraviețuiesc, ca elemente regionale sau arhaice, doar în spațiul romanic" (Milică 2010).

Țăranii trăitori în lumea satului românesc nu consumă usturoi în anumite sărbători: Tăierea Capului Sf. Prooroc Ioan Botezătorul - 29 Gustar [August]; Ziua Crucii-14 Răpciune [Septembrie]. Planta, considerată a fi hristologică, are un rol taumaturgic. Se pornește de la premisa că aiul are cap și cruce. Nu întâmplător, aiul era indispensabil steagului Călușarilor (Rusalii) și Sânzienelor - 24 Cireșar [Iunie]. Steagul Căluşarilor avea „năframe” [baticuri], usturoi, pelin, un șnur roșu. Steagul Sânzienelor/ Drăgaicelor era format din năframe, flori de sânziene, spice de grâu, usturoi, pelin.

\section{Aiul și legendele}

Aiul poate fi corelat cu legendele. Conform unei legende, Sânpetru [Sfântul Petru] vroia să se înalțe la cer. Îl păzea o sarcă. Această pasăre îi dădea de știre Nefârtatului ori de câte ori Sânpetru încerca să se înalțe la cer. Inițial, oamenii aveau tălpile drepte. Satan, atenționat de sarcă, l-ar fi prins pe Sânpetru de tălpi, smulgându-i bucăți de carne din ambele tălpi. Sfântul Petru, din pricina durerii ar fi strigat „ai” în loc de „au”: „de atunci, din cauza Diavolului, oamenii au tălpile adâncite la mijloc. Se crede că de durere, Sfântul Petru a strigat și de atunci a apărut aiul pe pământ:

- Ai, Doamne!

Dar Dumnezeu îi răspunse:

- Taci, Petre, că şi acela va fi de vreun folos!” (***Legendele faunei 1994: 3, 328).

$\mathbf{a}_{4}$ Sărbătoarea Drăgaica/Sânziana (lat. Gallium verum; lat. Gallium mollugo) (re) amintește de zeița agrară protectoare a lanurilor de grâu și a femeilor măritate. Diana Sancta, Iuno (Panteonul roman), Artemis, Hera (Panteonul grec) din mitologie pot fi corelate cu zeița agrară Sânziana/Drăgaica. Chiar dacă, în prezent, manifestarea agrară este supusă desacralizării, Al. Graur sesizează sacralitatea sărbătorii, latinitatea termenului: „lat. sanctus dies Iohannis «sfânta zi a lui Ion»” (1965: 52). Termenul sânziană/$e$ implică anumite izotopii:

$\mathbf{a}_{4 \mathbf{i}}$ izotopiefitomorfă. Florile de sânziene sunt galbene șialbe. În Țara Maramureșului se crede că zâna care se spală în râu, în noaptea de Sânziene, are veșminte din flori albe. În Țara Codrului, printre lanurile de cânepă se presară flori galbene de sânziene (magie simpatetică). Se crede că florile galbene de sânziene vor influența culoarea cânepii. 
Fetele cu status premarital, dorind să ị̂i viseze ursitul pun sub pernă flori albe sau galbene de sânziene. Totodată realizează cununi pe care le aruncă simbolic pe „hăizașul” [acoperișul] casei. Florile albe de sânziene trebuie corelate cu puritatea.

$\mathbf{a}_{4 \mathrm{ii}}$ izotopie sacră+eponimie. Florile galbene (re)amintesc de sărbătoarea creștină Nașterea Sfântului Ioan Botezătorul - Calendarul Creștin. Denumirea regională Sântion de Vară ne duce cu gândul la Sfântul Ioan Botezătorul (eponimie).

$\mathbf{a}_{4 \mathrm{iii}}$ izotopie umană + supraumană. Pluralul sânziene a generat singularul sânziană, devenit antroponim, nume de fată sau de reprezentare mitică feminină.

$\mathbf{a}_{\text {4iv }} \mathrm{Nu}$ întâmplător, sânzienele cu flori galbene (lat. Gallium verum) sunt denumite şi „,floarea Sfântului Ion” (Vasile 2010: 78). Conform medicinei populare românești, se crede că prin intermediul plantei se vindecă epilepsia. În spațiul cultural francez, remarcăm același aspect: „Sfântul Ioan Botezătorul este invocat aici în ipostaza sa de vindecător a ceea ce franceza populară numește «boala Sfântului Ioan»/Mal caduc sau Haut mal, adică epilepsie" (Mesnil 1997: 194). Plantele de leac ne duc cu gândul la medicina isihastă, care vindecă atât trupul, cât și sufletul (Vasile 2010: 46-56).

$a_{5}$ Sărbătorile pascale pot fi asociate cu anumite flori.

$\mathbf{a}_{\mathbf{5 i}}$ Floarea-Paștelui (Anemone nemorosa, fam. Ranunculaceae) trebuie corelată cu sărbătorile pascale. Se crede că floarea a apărut din lacrimile Mântuitorului Iisus Hristos, iar Maica Domnului, la cererea Mântuitorului, a răspândit-o în cele patru zări. Denumirile regionale subliniază sacralitatea plantei: „floarea Paștilor albă, floarea Sfintei Vineri, păștiţă, pâinea Paștelui” (Pârvu 2003: vol. II, D-L, 183). Se crede că aceste flori nu trebuie să lipsească de Paşti din lăcaşurile de cult; că masa de Paşti trebuie împodobită cu aceste flori: „Oamenii le culeg și le duc la biserică în vinerea Paștilor. De aceea le-au numit floarea Paștelui” (*** Legendele florei 1994: 2, 254); „Pretutindeni este în cinste. Cu ele se împodobește Sfânta Masă din Vinerea Mare. Nu este creștin care să nu aducă un buchețel și să-l pună cu evlavie pe masa ce închipuie Mormântul Mântuitorului din Vinerea Mare. Francezii îi spun Floarea Vinerii Sfinte (Fleur du Vendredi Saint)" (Simionescu 1947: 16).

$\mathbf{a}_{\text {sii }}$ Vioreaua (lat. Scilla bifolia L., fam. Liliaceae), denumită, în județul Maramureș, „furcuța Paștelui”, conform legendelor, apare în două ipostaze: izotopie umană - copilă/ fată bogată/fată săracă metamorfozată în floare; izotopie fitomorfă - floare propriu-zisă. Vioreaua poate fi corelată cu momentele esențiale din viața omului: nunta (cununa miresei); moartea (cununa tinerilor nelumiți): „Se făceau cu ele cununițe și se puneau pe mormântul fetelor și flăcăilor" (Butură 1979: 248).

b. Măcinicii (Calendarul Popular)/Sfinții din Sevastia (Calendarul Creștin) sunt sărbători care pot fi corelate cu o floare de primăvară. Remarcăm anumite contexte situaționale și anumite izotopii, care pot fi circumscrise florii respective:

$\mathbf{b}_{\mathbf{1}}$ izotopie gastronomică. Pe nouă martie, de Măcinici, în anumite zone ale țării, de exemplu, în Teleorman, se preparau bucate tradiționale în formă de opt, denumite „brânduși” sau „brândușei”: „Brânduşi cu chip de om, cu cap, se duc la biserică 
la Mucenici" (Marian 2011: 175). Bucatele tradiţionale (re)amintesc de martirii din Sevastia care au suferit martiriul: cercul de sus reprezintă cununa; cercul de jos reprezintă buzduganul cu care le-au fost sfărâmate gleznele. Mucenicii (rus. mučnik, „plăcintă de secară”) provine „prin deantroponimizare din numele primilor martiri ai creștinismului (< sl. mučeniku”) (Munteanu-Siserman 2015: 102).

$\mathbf{b}_{2}$ izotopiefitomorfă. Referindu-ne la planta propriu-zisă, se crede că mama vitregă a pământului scoate, în luna martie, afară din pământ brânduşele, pentru ca oamenii să le poată admira. Există brândușa de primăvară și brânduşa de toamnă. Metaforizând, bucatele tradiționale menționate mai sus ne duc cu gândul la brânduşa vieții și la brânduşa morții: „așa cum ne bucurăm noi de brânduși primăvara, când le vedem întâi, tot aşa se bucură și morții de ele" (Butură 1979: 48).

$\mathbf{b}_{3}$ izotopie antropomorfă. Conform unei legende, Busuioc a fost un fiu de împărat, îndrăgostit de Brândușa. Aceasta a fost răpită de un Zmeu, iar Busuioc a salvat-o: „Așa se face că astăzi e plină lumea de busuioc și brândușe, care sunt toți copiii și nepoții lor” (Vasile 2010: 208).

\section{Plantele asociate cu anumite discipline - etnologie, folclor, lingvistică, mitologie, religie}

c $_{1}$ Din perspectivă etnologică și folclorică, florile stau sub tutela profanului în momentul în care o femeie naște copii fără a fi căsătorită. Acei copii sunt denumiți și în prezent „copii din flori”. În trecut, copiii bastarzi căpătau nume de flori, indiferent de gen - masculin sau feminin: Crin/Crina; Florin/Florica; Viorel/Viorica etc.

c 2 Totodată, onomastica are un rol esențial când facem referire la antroponime care pot să fie asociate cu simboluri fitomorfe (flori) și dendromorfe (arbori, arbuști). În nord-vestul României, identificăm sufixe diminutivale în alcătuirea unor antroponime: *-el: Floricel, Bujorel; ${ }^{*}$ ica: Rozica; ${ }^{*}$-ina: Florina, Florentina ${ }^{6}$. În Maramureș, remarcăm prenume derivate, de la nume comune, inspirate din regnul vegetal: „Bujor, Bujorel, Camelia, Codruța, Crenguraș, Crina, Crinuța, Floarea, Florian, Floricel, Florica, Florin, Frăguța, Garofița, Jasmina, Lăcrămioara, Liliana, Violeta, Mugurel, Muruț, Crinuț, Narcis, Rozalica, Rozica, Strugurel, Violin, Viorel, Viorica" (O. Felecan 2009: 95). Atât numele inițial (convențional), cât și numele primite de individ ulterior (neconvenționale) au un status aparte: „Numele pe care îl conferim este, într-o foarte mare măsură, un conglomerat de experiențe de tot felul ale celui care numește și prea puțin sau deloc ale celui numit; este proiecția nominatorului despre sine sau despre cel numit” (D. Felecan 2014: 251).

$\mathbf{c}_{2 \mathrm{i}}$ Floriile sunt zeițe ale primăverii, personificări ale florilor, celebrate în Duminica Floriilor, peste care Biserica a suprapus sărbătoarea intrării Domnului în Ierusalim.

$\mathbf{c}_{2 \mathrm{ii}}$ Flora, zeița din mitologia romană, era stăpâna simbolurilor fitomorfe (flori) și

6 Vezi și alte exemple, alte sufixe diminutivale întrebuințate la alcătuirea antroponimelor maramureșene, la O. Felecan 2009: 94. 
dendromorfe (arbori). Conform Vechiului Calendar Roman, zeiței Flora îi corespundea luna Aprilie. Conform Calendarului Popular, denumirile regionale, alocate unor luni de primăvară (re)amintesc de zeița Flora: Florar, Luna Florilor - „Prier” [Aprilie] și Florariu, Frunzar - „Florar” [Mai].

Din perspectivă mitologică, se crede că zeiței Flora/nimfei grecești Chloris i se datorează apariția diferitelor specii de flori, inclusiv existența mierii. Floarea unică pe care Flora i-o oferă Iunonei pentru a-l naște pe Marte fără ajutor masculin subliniază sacralitatea florii respective aflate sub semnul anonimatului: „o floare a cărei simplă atingere făcea o femeie să rămână însărcinată” (Grimal 2003: 195).

$\mathbf{c}_{2 \mathrm{iii}}$ Se crede că gingaşul ghiocel (lat. Galanthus nivalis L., gr. gala < lapte, anthos $<$ floare albă, fam. Amayllidaceae) (it. bucaneve, fr. perceneige, engl. snowdrop, germ. glockenblume, rus. voiasisjnik, ucr. snijnoțvet), denumit în diverse regiuni ale țării noastre „aișoară, aișor, aiușoară, aiușor, clocoțăi de omăt, clopoței, clopoței albi, clopeți de primăvară, coconei, ghiocei mici, ghilicei, ghiocei de ghioc, ghiorele, gioare, gioreleluște, primăvăruță, primăveriță, usturoiță" (Pârvu 2003: 2, D-L, 294), datorită galantaminei, este planta sacră, misterioasă, de leac care îl salvează pe Ulise, astfel încât puterea vrăjitoarei Circe să nu se abată asupra sa: „Uite, floarea aceasta vrăjită e mai tare decât farmecul Circei. Și zeul îi dădu o floare de leac, albă ca zăpada, pe care numai zeii o puteau smulge din pământ” (Homer 2004: 102). Fitonimul menționat anterior poate să fie atât prenume, cât și poreclă: „Deosebirea constă în aceea că pentru prenume se selectează notele pozitive, în cazul dat, ale plantei: cu flori de un alb imaculat, frumoase, viguroase (întrucât apar primăvara foarte timpuriu), în timp ce pentru poreclă se are în vedere un aspect care, prin antiteză, devine negativ: Ghiocel este poreclit un individ cu tenul închis, brunet" (N. Felecan 2011: 372). Extrapolând, despre o persoană lipsită de personalitate se spune că adoptă poziția ghiocelului (este supus, stă cu capul plecat) în orice situație, inclusiv când, de exemplu, o autoritate (șeful) îl mustră pe nedrept.

$\mathbf{c}_{\text {2iv }}$ Coada şoricelului (lat. Achillea Millefolium). Latinescul millefolium „o mie de frunze"; Achillea provine de la Ahile. Se crede că eroul legendar, din mitologie, utiliza planta pentru a-și trata soldații. Remediile plantei: dureri de stomac, răni, tăieturi (Borza 1968: 10).

Ioan Milică (2010) precizează: „termenul Achillea s-a format de la numele grecesc al lui Ahile și denumește planta cu care marele erou l-ar fi vindecat pe Telephos, fiul lui Hercule, în schimbul promisiunii că acesta din urmă le va arăta aheilor drumul spre Troia”.

Denumiri regionale: Alunele, Brădățel, Ciureșică, Coada-şoarecii, Coada hârcelului, Coada-hârțului, Crestățea, Iarba-oilor, Iarba șoarecelui, Iarbă strănutătoare, Prisnel, Rotățele albe, Serocină, Șorecie, Țiță forcoteci (Borza 1968: 10).

$\mathbf{c}_{2 \mathrm{v}}$ Sita-Ielelor (Carlina Acaulis, denumiri regionale: turtă-rea, cioropor, spaimadracului, punga-babei, scaiul-dracului, ciurul-zânelor) și Frăsinel (Dictamnus fraxinella, denumire regională: floarea-focului), sunt legate de anumite făpturi mitologice, de Ielele care, pentru a le sista puterea tămăduitoare, le retează plantelor respective vârful. 
Persoanele care posedă o gândire empirică apelează la descântecele de speriat de Iele/de ceas rău pentru a-i salva pe bolnavii luați de Iele/pe bolnavii de epilepsie.

$\mathbf{c}_{3 \mathbf{i}}$ Ioan Milică, în studiul Imaginarul creștin în denumirile populare românești de plante (II) (2014), pornește de la premisa că imaginarul botanic creștin reflectă existența unor fitonime sintetice referitoare la: sfinți - georgițe (Convallaria majalis) < (Sf.) George + suf. -iță; sângiorgel (Pulmonaria angustifolia, Pulmonaria officinalis) < Sângeorgiu + suf. -el; sărbători care vizează Nașterea și Învierea Mântuitorului Iisus Hristos - crăciunele (Bergenia lingulata, Rhipsalis pachyptera $)<$ Crăciun + suf. -ele sau păștele (Anemone nemorosa) < Paște + suf. -ele; Fecioara Maria - mărioare (Callistephus chinensis) < Maria + suf. -ioare, denumire ce semnalează că planta ajunge la maturitate în preajma Adormirii Maicii Domnului (15 august); personaje biblice - rom. adămească (Ajuga laxmannii) < Adam + suf. -ească este o creație lexicală formată, cel mai probabil, după modelul altui fitonim, avrămească (Ajuga laxmannii); fințe celeste - rom. îngeraș (Begonia rex) < rom. înger + suf. -aș denumește o plantă al cărei nume este motivat de similaritatea pe care poporul a descoperit-o între aripile îngerilor și frunzele plantei; diavol - rom. drac a dat naștere unei ample terminologii etnobotanice constând atât din fitonime sintetice, precum dracă (Paliurus spina-christi, Xantium spinosum), drăcoaică (Paliurus spina-christi), drăcușor (Anthurus archeri); oameni ai bisericii - călugărei (Erythronium dens-canis) < călugăr + suf. -el, i; obiecte de cult - candeluță (Aquilegia vulgaris $)<$ candelă + suf. -uță, prescuriță (Sempervivum soboliferum) < prescură + suf. -iță (v. Milică 2014a).

\section{$c_{3 \mathrm{ii}}$ Palier morfosintactic}

Același cercetător, conchide, așa cum s-a menționat la începutul lucrării, că tipurile de compunere cel mai bine reprezentate în microvocabularul numelor de plante cu rezonanță creștină sunt cele dezvoltate prin:

A) subordonare acuzativală, realizată după schema [nume + prepoziție + nume] sau după schema [nume + adjectiv];

B) subordonare genitivală, realizată după schema [nume + nume propriu] sau după schema [nume + nume].

Pornind de la subordonarea acuzativală și genitivală, selectăm câteva exemple propuse de Ioan Milică:

A. subordonare acuzativală. Exemple: floare de Paști (Anenome nemorosa), rujă de Rusalii (Paeonia officinalis), treizeci-de-arginți (Lunaria annua) sau curelele de opinci ale Domnului Hristos (Triglochin palustre);

B. subordonare genitivală, în structuri denominative, cu trimitere la un element circumscris creștinismului (care poate ocupa, din punct de vedere sintactic, poziția de determinat sau determinant): Dumnezeu: cămaşa-Domnului (Convolvulus arvensis); iarba-lui-Dumnezeu (Artemisia arboratum); Fecioara Maria: acoperământul-Maicii (Ficus carica); brâul-Maicii-Domnului (Phalaris arundinacea); Sfinți: Sf. Gheorghe: floarea-Sângiorgiului (Corydalis cava), personaje biblice: Adam: palmalui-Adam (Symphytum officinale); Solomon: pecetea-lui-Solomon (Polygonatum); 
sărbători: Paștele: floarea-Paștelui (Anemone nemorosa); diavol: ardeiul-dracului (Polygonum hydropiper); banul-diavolului (Thlaspi arvense); oameni ai bisericii: popa: banul-popii (Lysimachia nummularia); barba-popii (Viola tricolor); raiul: cheița-raiului (Commelina communis, Zinnia elegans); floarea-raiului (Allium montanum, Chrysanthemum cinerarii folium, Geranium macrorrhizum); crucea: iarba-crucii (Hypericum perforatum), ziua-crucii (Aster salignus) (v. Milică 2014b).

$\mathbf{c}_{3 \mathrm{iii}}$ Uneori, plantele interacționează cu personalități emblematice, cu modele de conduită morală care au suferit martiriul - Mântuitorul Iisus, Maica Sfântă. Denumirile regionale anunță apropierea plantelor de divinitate (Dumnezeu, Mântuitorul Hristos, Fecioara Maria) și, aşa cum remarcă Milică, sesizăm că predomină subordonarea acuzativală/subordonarea genitivală.

Menționăm, în cele ce urmează, și alte exemple care au fost analizate, într-un alt studiu, dintr-o altă perspectivă ${ }^{7}$ :

$\mathbf{c}_{3 \text { iiix }}$ Denumiri care vizează divinitatea (Dumnezeu, Iisus Hristos): coroana lui Hristos - Euphorbia; floarea patimilor lui Hristos - Passiflora; inima Domnului - Dicentra spectabilis; lemnul lui Dumnezeu - Artemisia abrotana; lumânarea Domnului - Verbascum thapsus; ochiul lui Dumnezeu - Viola arvensis; scara Domnului - Polomonium caeruleum, eng. Jakob's ladder, fr. L'escalier de Dieu, germ. Jakobsleiter; săgeata Domnului - lat. La Verbena officinalis, fam. Verbenaceae.

$\mathbf{c}_{3 \text { iiiv }}$ Denumirile populare, alocate unor plante, anunță legătura acestora cu Maica Domnului: dorul Maicii Precista - Asplenium trichomanes; floarea Sfintei Mării - Aster salignus; iarba Sfintei Mării - Hierochloe odorata; inima Maicii Domnului - Dicentra spectabilis; lacrima Maicii Domnului - Hoya; măturița Maicii Domnului - Artemisia annua, fam. Compositae Asteracee; papucul Maicii Domnului - Cypripedium calciolus; părul Sfintei Mării - Asplenium trichomanes, fam. Polypodiaceae; poala Sfintei Mării - Nepeta pannonica, fam. Lamiaceae/Labiatae etc.

$\mathbf{c}_{3 \text { iiiz }}$ Există plante care interacționează cu sacrul, cu termeni religioși, cu elemente de cult creștin: cașul popii - Nalva silvestris, Nalva neglecta; cădelniță - Campanula carpatica); crucea pământului - Heracleum sphondylium, fam. Apiaceae/Umbelliferacee; crucea pâinii - Abutilon theophrasti; crucea voinicului - Hepatica nobilis, fam. Ranunculaceae; flori in cruci - Matthiola incana, fam. Cruciferae; flori de Ierusalim - Aster amellus, fam Compositae, gr. aster < stea; floarea luminii - Dictamnus albus, fam. Rutaceae; masa Raiului - Sedum fabaria; milostiva - Grațiola officinalis, lat. Gratia < milă, recunoștință; mila-Domnului - Ajuga laxmanni; pomul Raiului - Philadelphus coronarius, fam. Saxifragaceae; pristolnic - Abutillon teophrasti; scaunul Popii - Dianthus barbatus.

Dintre plantele menționate, câteva stârnesc curiozitatea. De exemplu, planta intitulată Brâul Maicii Domnului - Lychnis coronaria are și alte denumiri regionale: Barba Împăratului, Brâul cerului, Brâul Cosânzenei, Brâul lui Dumnezeu, Brâul popii, Curcubeu, Floarea cununii.

7 Vezi descrierea plantelor, corelarea acestora cu legendele, cu basmele la Răchișan 2013: $156-163$. 
Săgeata Domnului (La Verbena officinalis, fam. Verbenaceae), denumită și Buruiană de boală, Guşa-porumbelului, Măturică, Iarba spornică, Sporul casei, Verbina, considerată „iarba prezicerii” și „iarba sfântă”, se crede că ar fi crescut prima dată pe Muntele Calvarului. Planta trebuie culeasă de Sânziene. I se aduc ofrande: pâine, sare, o monedă de argint. Se crede că Săgeata Domnului ar fi vindecat rănile Mântuitorului. În schimb, planta Treizeci de arginți/Arginții lui Iuda (Lunaria annua), stă sub tutela profanului. Unii nu plantează planta în grădina lor, fiindcă o asociază cu trădarea lui Iuda față de Mântuitorul Iisus.

$\mathbf{c}_{3 \text { iiiv }}$ Sesizăm că în iconografie, uneori Maica Domnului este reprezentată având un crin alb (Lilium Candidum) într-o mână, iar alături de ea este înfățișat Iisus Împăratul. Crinul reprezintă neprihănirea și se crede că este „cea mai veche floare cultivată de om” (Vasile 2010: 131). Alteori, Arhanghelul Gavril este redat întinzându-i Maicii Domnului un buchet de crini albi când îi dă vestea nașterii Pruncului Sfânt; Iosif este înfățișat având în mână un crin alb, simbol al purității și al fecioriei Maicii Domnului. În iconografia catolică, Sfântul Anton de Padova este redat având crini albi în mână. Crinii, florile Sfântului Anton, sunt sfințiți în cadrul Sfintei Liturghii din 13 iunie. Tot atunci sunt binecuvântați și copiii ${ }^{8}$.

\section{Simboluri sacre dendromorfe și fitomorfe}

Extrapolând, nu doar simbolurile fitomorfe stau sub tutela sacrului, ci și anumite simboluri dendromorfe regăsite și în Sfânta Scriptură: cedru, isop, măslin, vița de vie etc. Cedrul, isopul și lână roșie erau indispensabile practicilor rituale: „lemnul de cedru simbolizează durabilitatea vieții în care omul intră după curățirea sa de necurățirile care îl atrăgeau spre păcat și asta ducea la moarte. Isopul simbolizează purificarea omului de necurăție, așa cum și regele David afirmă în Psalmul 50: «Stropi-mă-vei cu isop și mă voi curăța, spăla-mă-vei și mai vârtos decât zăpada mă voi albi» (psalm prezent și în slujba înmormântării), iar lâna roșie, viața care biruie moartea” (Ispas 2015: 47-48). Măslinul reprezintă veșnicia, ramura de măslin devine un simbol al păcii. După încetarea Potopului, pomenit în Sfânta Scriptură, porumbelul îi aduce lui Noe o ramură de măslin. Vița de vie este corelată cu viața, vinul, asociat cu sângele Mântuitorului, devine un simbol euharistic.

Simboluri fitomorfe sacre au un status aparte. Enumerăm câteva fitonime care pot fi corelate cu sacralitatea: macul, busuiocul, trifoiul.

$\mathbf{d}_{1}$ Macul (Papaver somniferum, familia Papaveraceae). Menționăm denumiri regionale cu referire la:

$\mathbf{d}_{1 \mathrm{i}}$ culoare: mac alb, mac albastru german, mac negru, mac roșu;

$\mathbf{d}_{1 \mathrm{ii}}$ calitate: mac bun;

$\mathbf{d}_{\text {1iii }}$ efect: somnişor [subst. somn + -işor].

Rol taumaturgic: „Se folosește în medicina populară pentru somnul copiilor și la hernie" (Borza 1968: 124).

\footnotetext{
8 http://www.ercis.ro/actualitate/viata.asp?id=20050633.
} 
Se crede că floarea de mac, inițial, a fost albă. După ce Iisus Hristos a fost răstignit pe cruce, câteva picături s-au prelins în cupa macului, modificându-i culoarea: „- De-acum înainte să fii roșie ca sângele pe care-l porți în cupa florilor tale!” $\left({ }^{* * *}\right.$ Legendele florei 1994: 2, 176).

$\mathbf{d}_{2}$ Busuiocul (gr. basilískos) este asociat cu Iisus Hristos, cu Maica Domnului, cu Bunul Dumnezeu.

$\mathbf{d}_{2 \mathrm{i}}$ a răsărit din sângele Mântuitorului: „busuiocul a răsărit pe lume când s-a născut Domnul Cristos [...]" (*** Legendele florei 1994: 2, 80);

$\mathbf{d}_{2 \mathrm{ii}}$ s-a ivit din lacrimile Sfintei Fecioare Maria: „s-a născut din lacrimile pe care Sfânta Maria le-a vărsat pe cruce" (*** Legendele florei 1994: 2, 79-80);

$\mathbf{d}_{2 \mathrm{iii}}$ Dumnezeu a botezat un nou-născut cu busuiocul: „a sortit copilului că, pe unde va merge, în urma lui să crească busuioc, cu care se va boteza lumea" (Vasile 2010: 209).

Pentru a-și păstra sacralitatea, busuiocul trebuie semănat de Sfântul Gheorghe (23 aprile) și cules de Sfânta Cruce (14 septembrie), apoi aninat, la icoane, pentru a fi uscat. Busuiocul este o plantă sfântă pentru că are capacitatea de a sacraliza apa - agheasma. În noaptea de Bobotează, fetele nemăritate merg la râu cu un mănunchi de busuioc și îl scufundă în apă. Cu apa topită, se spală pe față pentru a fi îndrăgite de feciori. De Paști, credincioșii se spală cu apa în care au inserat un ou roșu, un bănuț de argint și un fir de busuioc pentru a fi frumoși, drăgăstoși. De Sângiorz [de Sfântul Gheorghe] și de Sântandrei [de Sfântul Andrei], bătrânele din comunitatea tradițională din Maramureș, pentru a nu își pierde vaca laptele, adică mana, acroșau de ușa grajdului busuiocul legat cu un fir roșu.

$\mathbf{d}_{3}$ Trifoiul (engl. shamrach, arab. shamrakh < „Triadele persane”; irlan. seamrog < „trifoi mic”) este emblema Sfântului Patrik și implicit a Sfintei Treimi. În alte culturi, Sfântul Patrik este sărbătorit pe 17 Martie. În spaţiul cultural românesc, conform Calendarului Popular, pe 17 Mărțisor [Martie] se sărbătoresc Alexiile. Trifoiul cu patru foi trebuie corelat cu norocul datorită Evei din Biblie: „după izgonirea ei din Paradis, a luat unul ca amintire din Grădina Edenului” (Gibson 1998: 146).

\section{Antropomorfizarea și corelarea plantelor cu legendele}

Orice plantă este duală. Sesizăm, așa cum s-a mai menționat, o dialectică a contrariilor care se armonizează: sacru-profan; bine-rău; medicament-otravă; benign-malign. Printr-un proces de antropomorfizare sau „trecerea” în legende, plantele pot fi supuse unor metamorfoze, prin care fie se sacralizează, fie suferă o desacralizare.

$\mathbf{e}_{1}$ Mătrăguna (lat. Mandragora officinarum, botanică Atropa Belladonna) este o plantă respectată de români. Mătrăguna (lat. Mandragora officinarum, botanică Atropa Belladonna) este planta care a crescut în locul unde a fost creat de Dumnezeu, primul om, Adam (în ebraică: addam, it. uomo „om”, „bărbat”). Termenul atropa, corelat cu gr. atropos, (re)amintește de una dintre cele zece Moire (mitologie greacă)/Parce 
(mitologie romană), care influențau soarta oamenilor. Denumirea din limba latină belladonna, subliniază calitatea terapeutică a plantei și ne duce cu gândul la decoctul preparat de fete pentru a fi frumoase, pentru a le (stră)luci ochii - „midriaza” [dilatarea pupilei].

Apelativele, prin tendința de eufemizare, subliniază importanța pe care o acordă românii acestei plante, aspect confirmat de denumirile regionale: Împărăteasă/ Împărăteasa Ierburilor/Mare Doamnă/ Doamnă-Bună/ Floarea pădurii/ Cireașa lupului/ Poamă bună. Respectându-se praxis-ul ritualic, planta este culeasă pentru a face bine sau rău: noroc/ghinion; sărăcie/bogăție; căsătorie/separare, iubire/ură9 . Planta trebuie culeasă în zori, între Paști și Ispas [înălțare] de către femei fără veșminte. Planta este înconjurată de trei ori, i se aduc ofrande (pâine, sare, bani de argint, țuică/vin). Rădăcina plantei se aseamănă cu chipul ființei umane. În mediile tradiționale românești, există convingerea că planta plânge când este smulsă din pământ. Denumirile din limba engleză mandrake (engl. man „bărbat”) și womandrake (engl. woman „femeie”) potențează dualitatea - principiul masculin și feminin. Conform unei legende din Maramureș, mătrăguna a fost o fată frumoasă și bogată (izotopie umană), blestemată de niște bătrâne să se transforme în floare (izotopie fitomorfă): „„s-a rugat să fie lăsată să stea în locul unde este tăiată pădurea, unde-i lăzaștină. Care vor căuta-o și vor afla-o, ea le va fi de bun folos, dacă îi vor aduce bani, pască slujită, vin și miere de stup și alte mâncăruri alese" (***Antologie de folclor din județul Maramureș, 1980: 1-266). Atropina, hiosciamina, scopolamina sunt alcaloizi care influențează sistemul nervos central: „Se găsesc în diferite organe ale plantelor din familia Solonaceae (Atropa, Hyoscyamus, Scopolia, Datura, Anisodus, Duboisia, Mandragora) din care se extrag prin tehnica culturii de celule" (Milică 2009: 116). Nu întâmplător, când o persoană din pricina comportamentului neadecvat generează hybris [depășește limita, măsura], se spune: „Parcă a mâncat mătrăgună!”

Rol taumaturgic (medicina populară): remediu contra durerii de picioare, şale, mâini, friguri (Borza 1968: 27).

$\mathbf{e}_{2}$ Cicoarea (Cichorium intymbus), conform unei legende, este Zâna Florilor (izotopie supraumană) care nu dorea să se mărite cu Soarele. A fost pedepsită și metamorfozată într-un simbol fitomorf (izotopie fitomorfă): „Mi-o voi preface/în fragedă floare,/în floare de cicoare/cu ochii după soare;/când 'oi răsări/ea s-o-nveseli,/când 'oi asfinți,/ea s-o ofili” (Pamfile 2001: 57). Alteori, muritoarea care a aspirat la iubirea Soarelui, denumit în popor și „,ochiul sfânt” este metamorfozată în Floarea-Soarelui, denumită în popor „ochiul Soarelui”. Se crede că Floarea-Soarelui stă la poarta Raiului şi judecă florile. În ambele cazuri, remarcăm heliotropismul plantelor, care nu trebuie confundat cu solarismul/ cu heliolatria, cu perioada de solarizare a creștinismului „în care Dumnezeu-Fiul a trebuit să fie asimilat cu Soarele Sfânt” (Vulcănescu 1985: 365).

9 Vezi despre ritualul culegerii mătrăgunei, perspectiva comparativ-analitică (MaramureșSudul Dunării) la Răchișan 2013: 140-150. 
Rol taumaturgic (medicina populară): remediu contra gălbânării [hepatitei], e utilizată în cazul tăieturilor și rănilor (Borza 1968: 48).

\section{Concluzii}

Binaritatea sacru-profan subliniază complexitatea plantelor de leac care pot fi studiate din mai multe perspective. Denumirile regionale, denumirile științifice devin punct de conjuncție între sacru și profan. Perspectiva interdisciplinară (lingvistică, folclor, etnologie, mitologie, religie) subliniază complexitatea plantelor. Relația care se instituie între plante și sărbători, antropomorfizarea dezvăluie universul fascinant al plantelor. Categoriile folclorice, izotopiile, funcțiile fundamentale și subsidiare, rolul taumaturgic al fitonimelor determină glisarea dinspre etnologie înspre lingvistică.

\section{Bibliografie}

***Antologie de folclor din județul Maramureş, 1980. Poezia, Ion Chiş Şter (redactor responsabil), vol 1, Cuvânt Înainte de Mihai Pop, Colectivul de redacție: Pamfil Bilțiu, Ion Bogdan, Ion Chiş Şter, Mihai Dăncuş, Vasile Latiş, Vasile Leschian, Gheorghe Pop, Mihai Pop, Nicoară Timiş, Baia Mare: Asociaţia Etnografilor şi folcloriştilor din județul Maramureş.

*** Biblia. 1997. Tipărită sub îndrumarea și cu purtarea de grijă a Prea Fericitului Părinte Teoctist, Patriarhul Bisericii Ortodoxe Române, cu aprobarea Sfântului Sinod, București: Institutul Biblic și de Misiune al Bisericii Ortodoxe Române.

*** Dicționarul explicativ al limbii române, 1998. Ediția a II-a, Institutul de Lingvistică „Iorgu Iordan”, București: Academia Română, Univers Enciclopedic.

*** Legenda faunei. 1994. Ediţie critică şi studiu introductiv de Tony Brill, vol. 3. Bucureşti: „Grai şi Suflet - Cultura Națională”.

*** Legendele florei. 1994. Ediție critică şi studiu introductiv de Tony Brill, vol. 2. Bucureşti: „Grai şi suflet - Cultura Naţională”.

Borza, Al. 1968. Dicționar etnobotanic. București: Editura Academiei.

Butură, V. 1979. Enciclopedie de etnobotanică românească. București: Editura Științifică și Enciclopedică.

Butură, V. 1992. Cultură spirituală românească. București: Minerva.

Felecan, D. 2014. Pragmatica numelui și a numirii neconvenționale: de la paradigme teoretice la paradigme discursive. Cluj-Napoca: Mega \& Argonaut.

Felecan, N. 2011. Între lingvistică și filologie. Cluj-Napoca: Mega.

Felecan, O. 2009. Limba română în context european. Cluj-Napoca: Mega.

Graur, Al. 1965. Nume de persoane. Bucureşti: Ştiințifică.

Ghinoiu, I. 2002. Sărbători şi obiceiuri româneşti. Bucureşti: Elion.

Ghinoiu, I. 2005. Comoara satelor. Calendar popular. Bucureşti: Academia Română.

Ghinoiu, I. 2013. Dicționar. Mitologie românească. București: Univers Enciclopedic Gold.

Gibson, C. 1998. Semne \& Simboluri. Oradea: Aquila ,93.

Grimal, P. 2003. Dicționar de mitologie greacă și romană. București: Saeculum I. O.

Homer, 2004. Odiseea. București: Regis.

Ispas, S. 2015. Mărțișorul și relațiile lui cu timpul sacru. În Sub semnul mărțişorului, Varvara Buzilă (coord.), 41-55. Ministerul Culturii al Republicii Moldova, Muzeul Naţional de Etnografie și Istorie Naturală, Chișinău: Societatea de Etnologie din Republica Moldova. 
Marian, S. Fl., 2011. Sărbătorile la români. Păresimile, vol. II. București: Saeculum I. O.

Marian, S. Fl., 2000. Botanică românească. Bucureşti: Paideia.

Mesnil, M. 1997. Etnologul între şarpe şi balaur. București: Paideia.

Milică, C. I. 2009. Biotehnologiile viitorului. Iași: Tipo Moldova.

Munteanu-Siserman, M. 2015. Onomastica senzioralului gustativ. În Nume şi simţuri: corespondențe semantice în configurații denominative, 86-113. Cluj-Napoca: Editura Mega și Editura Argonaut.

Pamfile, T. 2001. Cerul şi podoabele lui. Ediție îngrijită de Antoaneta Olteanu. Bucureşti: Paideia. Pamfile, T. 1998. Dragostea în datina tineretului român. București: Editura Saeculum I. O.

Pîrvu, C. 2003. Enciclopedia plantelor. Plante din flora României, vol. II, D-L. Bucureşti: Tehnică.

Pop, M. 1998. Folclor românesc, vol. I. București: Grai şi Suflet.

Răchișan, D. A. 2013. Formulele magice și antropologia vârstelor. Magia cuvântului în Maramureș. București: Academia Română.

Răchișan, D. A. 2015. Nume de manifestări ritual-magico-simbolice între convențional și neconvențional. In Proceedings of the Third International Conference on Onomastics "Name and Naming", Conventional/Unconventional in Onomastics, September 1-3, 2015, Baia Mare, Oliviu Felecan (ed.), 806-818. Cluj-Napoca: Mega \& Argonaut.

Simionescu, I. 1947. Flora României. București: Fundația Regală Pentru Literatură și Artă.

Vasile, T. 2010. Flori în slujba vieții. Mărturii biblice. București: Pro Editura.

\section{Webografie}

Milică, I. 2010. Modele naive şi modele savante în reprezentarea lingvistică a realităţii: denumirile de plante. Limba Română 11-12 (anul XX). http://www.limbaromana.md/index. php?go=articole\&n=1077 (accesare site: 27 august 2017).

Milică I. 2014a. Imaginarul creştin în denumirile populare româneşti de plante (II). Limba română 4 (anul XXIV). http://www.limbaromana.md/index.php?go=articole\&n=2465 (accesare site: 29 august 2017).

Milică I. 2014b. Imaginarul creştin în denumirile populare româneşti de plante (III). Limba română 5 (anul XXIV). http://www.limbaromana.md/index.php?go=articole\&n=3050 (accesare site: 02 septembrie 2017 ).

http://www.ercis.ro/actualitate/viata.asp?id=20050633 (accesare site: 02. 09. 2017). 